\title{
Cardiovascular diseases, metabolic syndrome and health behaviours of postmenopausal women working in agriculture
}

\author{
Jarosław Pinkas ${ }^{1}$, Iwona Bojar ${ }^{2}$, Alfred Owoc ${ }^{3}$, Anna Wierzbińska-Stępniak², Dorota Raczkiewicz ${ }^{4}$
}

\author{
${ }^{1}$ School of Public Health, Centre of Postgraduate Medical Education, Warsaw, Poland \\ 2Department for Women's Health, Institute of Rural Health, Lublin, Poland \\ ${ }^{3}$ Centre for Public Health and Health Promotion, Institute of Rural Health, Lublin, \\ Poland \\ ${ }^{4}$ Institute of Statistics and Demography, Warsaw School of Economics, Warsaw, \\ Poland
}

Submitted: 20 February 2017

Accepted: 25 March 2017

Arch Med Sci 2017; 13, 5: 1040-1048

DOI: https://doi.org/10.5114/aoms.2017.68952

Copyright $\odot 2017$ Termedia \& Banach

\section{Abstract}

Introduction: The objective of the study was to examine the impact of occurrence of cardiovascular diseases (CVDs) and metabolic syndrome (MS) diagnoses on the frequency of health behaviours in postmenopausal women working in agriculture.

Material and methods: Eight hundred and ten postmenopausal women living in rural areas and working in agriculture, aged $46-70$ and at least 12 months from the last menstrual period, were examined. Analysis of variance with multiple comparison tests was used to compare the Inventory of Health Behaviours among the women with and without CVDs and MS.

Results: The frequency of some health behaviours, mainly health practices, is higher in postmenopausal women working in agriculture with CVDs or MS than in those without CVDs or MS $(p=0.045)$. Women with such disorders more often limit their physical effort $(p=0.029)$, try to be less overworked $(p<0.001)$ and to take more rest $(p=0.027)$, more often limit consumption of animal fat and sugar $(p=0.024)$, more regularly visit physicians $(p=0.003)$ and more often take seriously recommendations concerning their health. However, an insufficient frequency of health behaviours was observed among both the healthy women and those with metabolic disorders and CVDs. One third of all the examined women had a high frequency of health behaviours, one third had an average frequency and one third had a low frequency; hence actions should be taken to improve the situation.

Conclusions: Postmenopausal women working in agriculture more often perform beneficial health behaviours if they have MS and CVDs diagnosed in comparison to healthy women.

Key words: menopause, health behaviours, cardiovascular disease, metabolic syndrome.

\section{Introduction}

A significant part of an average woman's life (about 1/3) is the postmenopausal period. After menopause, due to expiry of the ovaries' generative function, hormonal changes occur in the female body, including a significant increase in follicle-stimulating hormone $(\mathrm{FSH})$ and luteinizing hormone (LH) concentrations and a significant decrease in oestradiol concentration.

\author{
Corresponding author: \\ Dorota Raczkiewicz \\ Institute of Statistics \\ and Demography \\ Warsaw School \\ of Economics \\ Niepodleglosci 162 \\ 02-554 Warsaw, Poland \\ Phone: +48 605313261 \\ E-mail: dbartos@sgh.waw.pl
}


Unfavourable changes in the lipid profile occur and cardiovascular diseases (CVDs) appear or intensify as a result of oestrogen deficiency [1]. Furthermore, due to reduced pancreas insulin secretion, the risk of type 2 diabetes grows. Such metabolic syndrome (MS) development indicators as abdominal obesity, hypertension, impaired glucose tolerance, low high density lipoprotein cholesterol (HDL-C) concentration and increased triglyceride (TG) concentration in blood serum are also common CVDs and type 2 diabetes risk factors [2]. The metabolic syndrome is caused by, among other factors, ageing, foetal programming, too little physical activity and improper diet [3]. The latest data based on animal models have led to the hypothesis that MS may be caused by a high intake of carbohydrates and fructose and relatively low intake of cholesterol and saturated fat [4].

The impact of these factors on CVDs and MS is widely discussed in the literature. A previous study performed in a group of obese women with MS showed significantly higher plasma levels of insulin as well as homeostatic model assessment insulin resistance than in the women without MS. In addition, the levels of visfatin, which is an adipokine secreted by visceral adipose tissue with insulin-mimetic properties, were similar in the analysed groups [5].

Women, for most of their lives, even at an old age, fulfil care and educational functions and in the sphere of family health they act as the leaders controlling health behaviours, including those of their husbands [6].

It is well known which health behaviours contribute to the prevalence and severity of metabolic disorders and cardiovascular diseases. An inverse relationship of cause and effect seems to be interesting, i.e. the impact of MS and CVDs diagnosis on the change of health behaviours.

The objective of the study was to examine the impact of MS and CVD diagnosis on the frequency of health behaviours in post-menopausal women working in agriculture.

\section{Material and methods}

\section{Study group}

The study was conducted in 2016 in Poland. The study group consisted of 810 randomly selected postmenopausal women, living in rural areas and working in agriculture. The inclusion criteria were: age 46-70 and at least 12 months from the last menstrual period. The exclusion criteria were: addiction to drugs or alcohol and a diagnosed disease entity with the symptoms of dementia. The medical examination of the presence and treatment of CVDs (arthrosclerosis, arterial hypertension, ischaemic heart disease), type 2 diabetes, dyslipidaemia, as well as the age and date of the last menstrual period, was conducted in the studied women. The blood pressure and waist circumference were measured in the examined women and their blood was collected to measure glucose concentration in the serum and lipid profiles. The total group of examined women was divided according to the presence of CVDs and MS into the following subgroups: both MS and CVDs, only CVDs, only MS, neither CVDs nor MS.

\section{Inventory of Health Behaviours}

The Inventory of Health Behaviours [7] contains 24 statements describing various health-related behaviours. The respondents mark how often they performed the provided activities during the last year, according to a 5-point scale, where 1 means 'almost never', 2 'rarely', 3 'sometimes, 4 'often', and 5 'almost always'. The sum of numerical values marked by the respondent gives the general health behaviours frequency indicator, which takes score values from 24 to 120 . The higher the result, the higher is the frequency of the declared health behaviours. The general health behaviours frequency indicator is converted into stens, which are then assessed within 3 intervals of results: low, average, and high. The frequencies of 4 health behaviour categories are calculated separately: nutritional habits, prophylactic behaviours, positive psychological attitude and health practices. Their indicators are mean numbers of scores obtained from the respondents' answers to individual statements and take score values from 1 to 5 .

\section{Definition of metabolic syndrome}

In order to diagnose MS, as defined according to the International Diabetes Federation in 2005, it is necessary to find at least three of the five following abnormalities:

1) abdominal obesity (waist circumference $\geq 80 \mathrm{~cm}$ in women);

2) hypertriglyceridaemia (triglyceride $\geq 150 \mathrm{mg} / \mathrm{dl}$ or current use of medication treatment for dyslipidaemia);

3) low HDL-C (HDL-C $<50 \mathrm{mg} / \mathrm{dl}$ in women or current use of medication treatment for dyslipidaemia);

4) arterial hypertension (systolic blood pressure $\geq 130 \mathrm{~mm} \mathrm{Hg}$ or diastolic blood pressure $\geq 85$ $\mathrm{mm} \mathrm{Hg}$ or current use of antihypertensive medication);

5) hyperglycaemia (blood glucose level with empty stomach $\geq 100 \mathrm{mg} / \mathrm{dl}$ or current use of medication for type 2 diabetes).

\section{Statistical analysis}

The results were statistically analysed using Statistica 10.0 PL (StatSoft Inc., USA). We estimat- 
ed mean values $(M)$ with standard deviations $(S D)$ estimated for continuous variables, and absolute $(n)$ and relative numbers (\%) of occurrence of items for categorical variables. We used the $\chi^{2}$ test to compare categorical variables and the $\mathrm{F}$ analysis of variance test to compare continuous variables between the 4 groups of women examined. We also estimated multiple comparisons using the least significant difference test. The value of $p<0.05$ was considered to indicate a statistically significant difference.

Informed consent for participation in the study was obtained from the women. The study was approved by the Ethics Committee of the Institute of Rural Medicine in Lublin, Poland.

\section{Results}

\section{Characteristics of the study group}

Eight hundred and ten postmenopausal women working in agriculture were examined. Four hundred and seven of them, i.e. $50.3 \%$, were di- agnosed with at least one CVD. Four hundred and sixty-one women examined, i.e. 57\%, had MS (fulfilled at least 3 of 5 MS criteria). Of the entire sample, 129 (16\%) women had CVD alone, 183 (23\%) MS alone, 278 (34\%) both the conditions and 220 (27\%) women neither of them.

Age, age of last menstruation and menopause duration differed significantly between the four groups of women examined (Table I). The women examined with both the MS and CVDs were the oldest, had the last menstruation later and their menopause lasted longer compared to the women examined without MS and CVDs. The women examined with only CVDs were older and had the last menstruation later compared to the women examined with only MS (Table II).

The women examined with both MS and CVDs were the highest educated, whereas the women without MS and CVDs were the lowest. Between them was the educational level of the women examined with only MS or with only CVDs (Table III).

Table I. Characteristics of the examined women

\begin{tabular}{|lcccccccccccc|}
\hline Characteristics & $\begin{array}{c}\text { Total } \\
(N=810)\end{array}$ & $\begin{array}{c}\text { None } \\
(n=220)\end{array}$ & $\begin{array}{c}\text { Only CVDs } \\
(n=129)\end{array}$ & $\begin{array}{c}\text { Only MS } \\
(n=183)\end{array}$ & $\begin{array}{c}\text { Both MS } \\
\text { and CVDs } \\
(n=278)\end{array}$ & Comparison \\
\cline { 2 - 13 } & $M$ & $S D$ & $M$ & $S D$ & $M$ & $S D$ & $M$ & $S D$ & $M$ & $S D$ & $F$ & $p$ \\
\hline Age [years] & 57.8 & 5.5 & 55.8 & 4.6 & 58.6 & 5.2 & 57.3 & 5.8 & 59.4 & 5.6 & 20.290 & $<0.001$ \\
\hline $\begin{array}{l}\text { Age at last } \\
\text { menstruation [years] }\end{array}$ & 50.3 & 4.0 & 49.9 & 3.6 & 51.0 & 3.9 & 50.0 & 4.4 & 50.6 & 3.9 & 3.145 & 0.025 \\
\hline $\begin{array}{l}\text { Menopause duration } \\
\text { [years] }\end{array}$ & 7.5 & 5.3 & 5.9 & 4.3 & 7.6 & 5.3 & 7.3 & 5.4 & 8.8 & 5.6 & 12.802 & $<0.001$ \\
\hline
\end{tabular}

Table II. Multiple comparisons of characteristics of the examined women

\begin{tabular}{|c|c|c|c|c|c|c|}
\hline Characteristics & $\begin{array}{l}\text { None } \\
\text { vs. only } \\
\text { CVDs }\end{array}$ & $\begin{array}{c}\text { None } \\
\text { vs. only } \\
\text { MS }\end{array}$ & $\begin{array}{l}\text { None } \\
\text { vs. both MS } \\
\text { and CVDs }\end{array}$ & $\begin{array}{l}\text { Only CVDs } \\
\text { vs. only MS }\end{array}$ & $\begin{array}{l}\text { Only CVDs } \\
\text { vs. both MS } \\
\text { and CVDs }\end{array}$ & $\begin{array}{l}\text { Only MS } \\
\text { vs. both MS } \\
\text { and CVDs }\end{array}$ \\
\hline Age [years] & $<0.001$ & 0.004 & $<0.001$ & 0.043 & 0.140 & $<0.001$ \\
\hline Age at last menstruation [years] & 0.010 & 0.792 & 0.042 & 0.024 & 0.340 & 0.098 \\
\hline Menopause duration [years] & 0.004 & 0.006 & $<0.001$ & 0.716 & 0.025 & 0.003 \\
\hline
\end{tabular}

Table III. Educational level of the examined women

\begin{tabular}{|c|c|c|c|c|c|c|c|c|c|c|}
\hline \multirow[t]{2}{*}{ Educational level } & \multicolumn{2}{|c|}{ Total } & \multicolumn{2}{|c|}{ None } & \multicolumn{2}{|c|}{ Only CVDs } & \multicolumn{2}{|c|}{ Only MS } & \multicolumn{2}{|c|}{$\begin{array}{l}\text { Both MS } \\
\text { and CVDs }\end{array}$} \\
\hline & $n$ & $\%$ & $n$ & $\%$ & $n$ & $\%$ & $n$ & $\%$ & $n$ & $\%$ \\
\hline $\begin{array}{l}\text { Primary not completed or } \\
\text { without any education }\end{array}$ & 19 & 2.35 & 3 & 1.36 & 0 & 0.00 & 5 & 2.73 & 11 & 3.96 \\
\hline Primary & 173 & 21.36 & 39 & 17.73 & 30 & 23.26 & 34 & 18.58 & 70 & 25.18 \\
\hline Basic vocational & 293 & 36.17 & 75 & 34.09 & 45 & 34.88 & 70 & 38.25 & 103 & 37.05 \\
\hline Secondary & 303 & 37.41 & 92 & 41.82 & 53 & 41.09 & 69 & 37.70 & 89 & 32.01 \\
\hline Tertiary & 22 & 2.72 & 11 & 5.00 & 1 & 0.78 & 5 & 2.73 & 5 & 1.80 \\
\hline
\end{tabular}


Table IV. Number of MS criteria in the examined women

\begin{tabular}{|ccccccccccc|}
\hline \multirow{2}{*}{$\begin{array}{c}\text { Number } \\
\text { of MS criteria }\end{array}$} & \multicolumn{2}{c}{ Total } & \multicolumn{2}{c}{ None } & \multicolumn{2}{c}{ Only CVDs } & \multicolumn{2}{c|}{ Only MS } & \multicolumn{2}{c|}{ Both MS and CVDs } \\
\cline { 2 - 11 } & $n$ & $\%$ & $n$ & $\%$ & $n$ & $\%$ & $n$ & $\%$ & $n$ & $\%$ \\
\hline $0-2$ & 349 & 43.09 & 220 & 100.00 & 129 & 100.00 & 0 & 0.00 & 0 & 0.00 \\
\hline 0 & 8 & 0.99 & 8 & 3.64 & 0 & 0.00 & 0 & 0.00 & 0 & 0.00 \\
\hline 1 & 73 & 9.01 & 63 & 28.64 & 10 & 7.75 & 0 & 0.00 & 0 & 0.00 \\
\hline 2 & 268 & 33.09 & 149 & 67.73 & 119 & 92.25 & 0 & 0.00 & 0 & 0.00 \\
\hline $3-5$ & 461 & 56.91 & 0 & 0.00 & 0 & 0.00 & 183 & 100.00 & 278 & 100.00 \\
\hline 3 & 292 & 36.05 & 0 & 0.00 & 0 & 0.00 & 123 & 67.21 & 169 & 60.79 \\
\hline 4 & 114 & 14.07 & 0 & 0.00 & 0 & 0.00 & 44 & 24.04 & 70 & 25.18 \\
\hline 5 & 55 & 6.79 & 0 & 0.00 & 0 & 0.00 & 16 & 8.74 & 39 & 14.03 \\
\hline
\end{tabular}

$\chi^{2}=880.924, p<0.001$.

Table V. MS characteristics in the examined women

\begin{tabular}{|c|c|c|c|c|c|c|c|c|c|c|c|c|}
\hline \multirow[t]{2}{*}{ Criteria } & \multicolumn{2}{|c|}{ Total } & \multicolumn{2}{|c|}{ None } & \multicolumn{2}{|c|}{ Only CVDs } & \multicolumn{2}{|c|}{ Only MS } & \multicolumn{2}{|c|}{$\begin{array}{l}\text { Both MS and } \\
\text { CVDs }\end{array}$} & \multicolumn{2}{|c|}{ Comparison } \\
\hline & $n$ & $\%$ & $n$ & $\%$ & $n$ & $\%$ & $n$ & $\%$ & $n$ & $\%$ & $\chi^{2}$ & $P$-value \\
\hline Abdominal obesity & 742 & 91.60 & 172 & 78.18 & 113 & 87.60 & 183 & 100.00 & 274 & 98.56 & 88.503 & $<0.001$ \\
\hline Hypertriglyceridaemia & 193 & 23.83 & 5 & 2.27 & 2 & 1.55 & 71 & 38.80 & 115 & 41.37 & 161.305 & $<0.001$ \\
\hline Low HDL-C & 147 & 18.15 & 3 & 1.36 & 1 & 0.78 & 48 & 26.23 & 95 & 34.17 & 124.036 & $<0.001$ \\
\hline Arterial hypertension & 693 & 85.56 & 129 & 58.64 & 121 & 93.80 & 169 & 92.35 & 274 & 98.56 & 180.981 & $<0.001$ \\
\hline Hyperglycaemia & 441 & 54.44 & 52 & 23.64 & 11 & 8.53 & 154 & 84.15 & 224 & 80.58 & 335.506 & $<0.001$ \\
\hline
\end{tabular}

\section{Characteristics of metabolic syndrome}

The four groups of examined women differed significantly in the number of MS criteria (Table IV) and prevalence of each criterion (Table $\mathrm{V}$ and Figure 1). The women examined with both MS and CVDs had a similar percentage of 3, 4 and 5 MS criteria fulfilled as the women examined with only MS. 2/3 of the women examined with neither MS nor CVDs had 2 MS criteria fulfilled, $29 \%$ of them had 1 criterion and $4 \%$ had none. The women examined with only CVDs most often fulfilled 2 MS criteria (92\%), 1 criterion was fulfilled by $8 \%$ and no criterion was fulfilled by none of the women examined with only CVDs.

In general, most of the examined women had abdominal obesity: all the women examined with only MS, almost all with both MS and CVDs and a majority with only CVDs or with neither MS nor CVDs.

Slightly fewer of the examined women had arterial hypertension: almost all the women with both MS and CVDs, with only CVDs or only MS and a significantly lower percentage of the women with neither MS nor CVDs.

Hyperglycaemia was third in the order of prevalence of MS criteria in the examined women (about half of the total sample): a similar majority of the women with both MS and CVDs and with only MS, but a significantly lower percentage of the women with only CVDs, and the lowest percentage of those with neither MS nor CVDs.

Hypertriglyceridaemia was fourth in the order of prevalence of MS criteria in the examined women (about $1 / 4$ of the total sample): a similar percentage of the women with both MS and CVDs and with only MS, but almost none of the women with only CVDs or with neither MS nor CVDs.

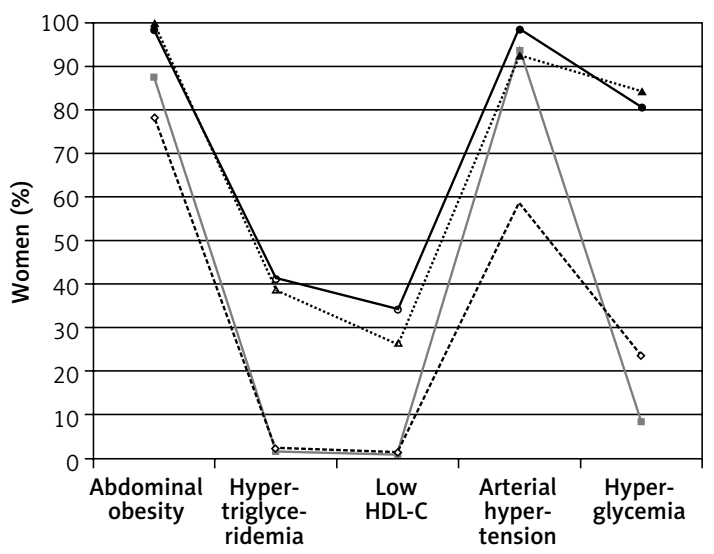

$\cdots$ None $\quad-$ Only CVDs $\cdots \cdots$ Only MS $\rightarrow$ Both MS and CVDs

Figure 1. Percentage of the examined women with MS criteria 
The lowest prevalence of MS criteria was observed for HDL-C: a similar percentage of the women with both MS and CVDs and with only MS, but almost none of the women with only CVDs or with neither MS nor CVDs.

\section{Frequency of health behaviours}

The general health behaviours frequency indicator did not differ significantly between the women examined with CVDs and without CVDs or among the 4 groups of women examined. About $1 / 3$ of each subgroup in the study (with both the MS and CVDs, with only CVDs, with only MS, with neither MS nor CVDs) had a low, average or high frequency of health behaviours (Table VI).

On the whole, the examined women most often observed the medical recommendations resulting from their examinations, had friends and a regular family life, limited their tobacco consumption, and had written down (knew) the telephone numbers of ambulance services, whereas least frequently they limited the consumption of animal fat and sugar, avoided being overworked and excessive physical effort, controlled their body weight, and took sufficient rest (Table VII).

The four groups of examined women differed significantly in one correct nutritional habit - limited consumption of animal fat and sugar, in one prophylactic behaviour - regularly reporting for health checkups, in one positive psychological attitude - taking seriously recommendations from those who express concern about their health, in health practices in general and three of them: taking sufficient rest, avoiding being overworked and avoiding excessive physical effort (Table VII).

The examined women with both MS and CVDs performed all the above-mentioned health behaviours more often than the examined women with only MS or those with neither MS nor CVDs (Table VIII).

The frequency of all the above-mentioned health behaviours did not significantly differ between the examined women with only CVDs, with only MS and with none of the disorders.

Two of the above-mentioned health behaviours - taking sufficient rest and avoiding being overworked - were performed by the examined women with both MS and CVDs more often than by those with only CVDs. The other health behaviours were performed with the same frequency by the examined women with both MS and CVDs as by those with only CVDs.

Other correct nutritional habits such as avoiding salt or heavily salted foods and those containing preservatives, as well as eating a lot of vegetables, fruits, and whole grain bakery products, were equally often performed by healthy women as by those with metabolic disorders and with CVDs.

\section{Discussion}

The results of our study confirm the high prevalence of MS and CVDs in women after menopause. At least one cardiovascular disease was found in $50 \%$ and MS in $57 \%$ of the tested women; moreover, $34 \%$ were diagnosed with both the disorders.

The aim of this study was to analyse the impact of CVD and MS occurrence in postmenopausal women working in agriculture on the frequency of their health behaviours. The overall indicator of health behaviours in the studied women with/without CVDs or MS was at an average level. This indicator involves preventive measures, health practices, positive mental attitude and proper eating habits. Correct nutritional habits were observed by the examined women with a relatively low frequency, 3.4 on average, which means between sometimes and often. The women with CVDs and MS more often reduced the consumption of animal fats and sugar than the women without those disorders. Different results were obtained in the studies EUROASPIRE I and II, performed on approximately 3500 people with advanced coronary artery disease living in Germany, the Czech Republic, Finland, France, Spain, Slovenia, Hungary and Italy. In these people the number of CVD risk factors increased, although they were aware of the hazards. Within four years the frequency of obesity increased from $25.3 \%$ to $32.8 \%$. Hypertension was at a similar level of $55.4 \%$ vs. $53.9 \%$. Only the excessive total cholesterol (TC) concentration decreased from $86.2 \%$ to $58.8 \%$ [8].

Another health behaviour of the surveyed postmenopausal women was undertaking health practices, e.g. control of body weight. Ensuring correct weight, understood as a body mass index (BMI)

Table VI. General indicator of health behaviours frequency according to CVDs and MS in the examined women

\begin{tabular}{|lcccccccccc|}
\hline $\begin{array}{l}\text { General indicator } \\
\text { of health behaviours } \\
\text { frequency }\end{array}$ & \multicolumn{2}{c}{ Total } & \multicolumn{2}{c}{ None } & \multicolumn{2}{c}{ Only CVDs } & \multicolumn{2}{c|}{ Only MS } & \multicolumn{2}{c|}{ Both MS and CVDs } \\
\hline Low & $n$ & $\%$ & $n$ & $\%$ & $n$ & $\%$ & $n$ & $\%$ & $n$ & $\%$ \\
\hline Average & 271 & 33.46 & 76 & 34.55 & 44 & 34.11 & 64 & 34.97 & 87 & 31.29 \\
\hline High & 301 & 37.16 & 78 & 35.45 & 47 & 36.43 & 80 & 43.72 & 96 & 34.53 \\
\hline
\end{tabular}

$\chi^{2}=9.689, p=0.138$ 
Table VII. Health behaviours frequency in the examined women

\begin{tabular}{|c|c|c|c|c|c|c|c|c|c|c|c|c|}
\hline \multirow[t]{2}{*}{ Health behaviours } & \multicolumn{2}{|c|}{ Total } & \multicolumn{2}{|c|}{ None } & \multicolumn{2}{|c|}{ Only CVDs } & \multicolumn{2}{|c|}{ Only MS } & \multicolumn{2}{|c|}{$\begin{array}{l}\text { Both MS } \\
\text { and CVDs }\end{array}$} & \multicolumn{2}{|c|}{ Comparison } \\
\hline & $M$ & $S D$ & $M$ & $S D$ & $M$ & $S D$ & $M$ & $S D$ & $M$ & $S D$ & $F$ & $P$-value \\
\hline \multicolumn{13}{|l|}{ Correct nutritional habits: } \\
\hline Total & 3.37 & 0.71 & 3.38 & 0.69 & 3.41 & 0.71 & 3.27 & 0.71 & 3.41 & 0.74 & 1.603 & 0.187 \\
\hline $\begin{array}{l}\text { I eat a lot of vegetables } \\
\text { and fruits }\end{array}$ & 3.63 & 0.92 & 3.68 & 0.87 & 3.57 & 0.95 & 3.60 & 0.92 & 3.64 & 0.94 & 0.508 & 0.677 \\
\hline $\begin{array}{l}\text { I limit consumption } \\
\text { of such products as } \\
\text { animal fat and sugar }\end{array}$ & 3.17 & 1.10 & 3.08 & 1.05 & 3.26 & 1.11 & 3.03 & 1.07 & 3.31 & 1.14 & 3.166 & 0.024 \\
\hline $\begin{array}{l}\text { I care about correct } \\
\text { nutrition }\end{array}$ & 3.45 & 1.06 & 3.46 & 1.07 & 3.39 & 1.09 & 3.44 & 1.02 & 3.48 & 1.08 & 0.246 & 0.864 \\
\hline $\begin{array}{l}\text { I avoid consuming } \\
\text { food containing } \\
\text { preservatives }\end{array}$ & 3.30 & 1.15 & 3.26 & 1.15 & 3.43 & 1.16 & 3.19 & 1.11 & 3.33 & 1.16 & 1.352 & 0.256 \\
\hline $\begin{array}{l}\text { I avoid salt and heavily } \\
\text { salted food }\end{array}$ & 3.36 & 1.18 & 3.38 & 1.15 & 3.42 & 1.20 & 3.17 & 1.14 & 3.45 & 1.21 & 2.257 & 0.080 \\
\hline $\begin{array}{l}\text { I eat wholegrain bakery } \\
\text { products }\end{array}$ & 3.30 & 1.17 & 3.41 & 1.15 & 3.37 & 1.17 & 3.20 & 1.18 & 3.26 & 1.18 & 1.415 & 0.237 \\
\hline \multicolumn{13}{|l|}{ Prophylactic behaviours: } \\
\hline Total & 3.68 & 0.70 & 3.70 & 0.68 & 3.65 & 0.72 & 3.58 & 0.70 & 3.74 & 0.69 & 2.235 & 0.083 \\
\hline I avoid colds & 3.54 & 1.14 & 3.65 & 1.11 & 3.53 & 1.19 & 3.48 & 1.13 & 3.48 & 1.14 & 1.149 & 0.328 \\
\hline $\begin{array}{l}\text { I have written down } \\
\text { (I know) the telephone } \\
\text { numbers of ambulance } \\
\text { services }\end{array}$ & 3.89 & 1.33 & 4.04 & 1.24 & 3.76 & 1.42 & 3.84 & 1.34 & 3.86 & 1.35 & 1.483 & 0.218 \\
\hline $\begin{array}{l}\text { I observe medical } \\
\text { recommendations } \\
\text { resulting from my } \\
\text { examinations }\end{array}$ & 4.15 & 0.99 & 4.18 & 0.99 & 4.06 & 1.02 & 4.09 & 0.99 & 4.22 & 0.97 & 1.074 & 0.359 \\
\hline $\begin{array}{l}\text { I regularly report for } \\
\text { health checkups }\end{array}$ & 3.57 & 1.20 & 3.42 & 1.22 & 3.65 & 1.14 & 3.40 & 1.21 & 3.76 & 1.18 & 4.812 & 0.003 \\
\hline $\begin{array}{l}\text { I try to find out how } \\
\text { others avoid diseases }\end{array}$ & 3.21 & 1.15 & 3.22 & 1.18 & 3.11 & 1.21 & 3.07 & 1.05 & 3.33 & 1.16 & 2.252 & 0.081 \\
\hline $\begin{array}{l}\text { I try to obtain medical } \\
\text { information and un- } \\
\text { derstand the causes of } \\
\text { health and disease }\end{array}$ & 3.72 & 1.08 & 3.71 & 1.16 & 3.78 & 1.09 & 3.58 & 1.03 & 3.80 & 1.04 & 1.678 & 0.170 \\
\hline \multicolumn{13}{|c|}{ Positive psychological attitude: } \\
\hline Total & 3.58 & 0.71 & 3.59 & 0.73 & 3.57 & 0.74 & 3.56 & 0.66 & 3.60 & 0.72 & 0.133 & 0.940 \\
\hline $\begin{array}{l}\text { I take seriously recom- } \\
\text { mendations from those } \\
\text { who express concern } \\
\text { about my health }\end{array}$ & 3.45 & 1.15 & 3.32 & 1.15 & 3.38 & 1.25 & 3.44 & 1.17 & 3.59 & 1.09 & 2.497 & 0.059 \\
\hline $\begin{array}{l}\text { I avoid situations } \\
\text { which have a depress- } \\
\text { ing effect on me }\end{array}$ & 3.31 & 1.12 & 3.30 & 1.12 & 3.37 & 1.20 & 3.32 & 1.12 & 3.29 & 1.09 & 0.180 & 0.910 \\
\hline $\begin{array}{l}\text { I try to avoid exces- } \\
\text { sively strong emotions, } \\
\text { stress and tensions }\end{array}$ & 3.29 & 1.11 & 3.27 & 1.06 & 3.37 & 1.14 & 3.20 & 1.06 & 3.34 & 1.18 & 0.811 & 0.488 \\
\hline $\begin{array}{l}\text { I have friends and } \\
\text { a regular family life }\end{array}$ & 4.13 & 1.08 & 4.20 & 1.04 & 3.99 & 1.25 & 4.19 & 1.02 & 4.10 & 1.07 & 1.294 & 0.275 \\
\hline $\begin{array}{l}\text { I avoid such feelings } \\
\text { as anger, anxiety and } \\
\text { depression }\end{array}$ & 3.45 & 1.12 & 3.48 & 1.17 & 3.47 & 1.19 & 3.38 & 1.02 & 3.47 & 1.11 & 0.296 & 0.828 \\
\hline I think positively & 3.86 & 0.98 & 3.98 & 1.01 & 3.86 & 0.93 & 3.81 & 0.95 & 3.80 & 0.98 & 1.521 & 0.208 \\
\hline
\end{tabular}


Table VII. Cont.

\begin{tabular}{|c|c|c|c|c|c|c|c|c|c|c|c|c|}
\hline \multirow[t]{2}{*}{ Health behaviours } & \multicolumn{2}{|c|}{ Total } & \multicolumn{2}{|c|}{ None } & \multicolumn{2}{|c|}{ Only CVDs } & \multicolumn{2}{|c|}{ Only MS } & \multicolumn{2}{|c|}{$\begin{array}{l}\text { Both MS } \\
\text { and CVDs }\end{array}$} & \multicolumn{2}{|c|}{ Comparison } \\
\hline & $M$ & $S D$ & $M$ & $S D$ & $M$ & $S D$ & $M$ & $S D$ & $M$ & $S D$ & $F$ & $P$-value \\
\hline \multicolumn{13}{|l|}{ Health practices: } \\
\hline Total & 3.33 & 0.71 & 3.28 & 0.71 & 3.29 & 0.70 & 3.26 & 0.67 & 3.42 & 0.74 & 2.692 & 0.045 \\
\hline I take sufficient rest & 3.11 & 1.01 & 3.02 & 1.00 & 3.02 & 1.02 & 3.05 & 0.98 & 3.26 & 1.03 & 3.086 & 0.027 \\
\hline $\begin{array}{l}\text { I avoid being over- } \\
\text { worked }\end{array}$ & 2.91 & 1.15 & 2.76 & 1.12 & 2.82 & 1.20 & 2.78 & 1.13 & 3.15 & 1.14 & 6.304 & $<0.001$ \\
\hline $\begin{array}{l}\text { I control my body } \\
\text { weight }\end{array}$ & 3.17 & 1.17 & 3.22 & 1.20 & 3.23 & 1.16 & 3.02 & 1.13 & 3.20 & 1.17 & 1.396 & 0.243 \\
\hline I get sufficient sleep & 3.64 & 1.11 & 3.54 & 1.03 & 3.56 & 1.20 & 3.73 & 1.12 & 3.71 & 1.12 & 1.641 & 0.178 \\
\hline $\begin{array}{l}\text { I limit my tobacco } \\
\text { consumption }\end{array}$ & 3.96 & 1.41 & 4.05 & 1.35 & 3.97 & 1.46 & 3.94 & 1.39 & 3.90 & 1.44 & 0.538 & 0.657 \\
\hline $\begin{array}{l}\text { I avoid excessive } \\
\text { physical effort }\end{array}$ & 3.17 & 1.15 & 3.11 & 1.15 & 3.12 & 1.17 & 3.02 & 1.12 & 3.32 & 1.14 & 3.030 & 0.029 \\
\hline
\end{tabular}

Table VIII. Multiple comparisons of health behaviours frequency in the examined women

\begin{tabular}{|lcccccc|}
\hline Health behaviours & $\begin{array}{c}\text { None } \\
\text { vs. only } \\
\text { CVDs }\end{array}$ & $\begin{array}{c}\text { None vs. } \\
\text { only MS }\end{array}$ & $\begin{array}{c}\text { None vs. } \\
\text { both MS } \\
\text { and CVDs }\end{array}$ & $\begin{array}{c}\text { Only } \\
\text { CVDs vs. } \\
\text { only MS }\end{array}$ & $\begin{array}{c}\text { Only } \\
\text { CVDs } \\
\text { Both MS } \\
\text { and CVDs }\end{array}$ & $\begin{array}{c}\text { Only MS } \\
\text { vs. both } \\
\text { MS } \text { and } \\
\text { CVDs }\end{array}$ \\
\hline $\begin{array}{l}\text { I limit consumption of such products as } \\
\text { animal fat and sugar }\end{array}$ & 0.142 & 0.685 & 0.021 & 0.077 & 0.669 & 0.009 \\
\hline I regularly report for health checkups & 0.084 & 0.842 & 0.002 & 0.066 & 0.412 & 0.002 \\
\hline $\begin{array}{l}\text { I take seriously recommendations from } \\
\text { those who express concern about my } \\
\text { health }\end{array}$ & 0.629 & 0.302 & 0.009 & 0.665 & 0.087 & 0.164 \\
\hline Health practices - general & 0.980 & 0.675 & 0.032 & 0.697 & 0.074 & 0.014 \\
\hline I take sufficient rest & 0.948 & 0.793 & 0.011 & 0.711 & 0.026 & 0.032 \\
\hline I avoid being overworked & 0.622 & 0.845 & $<0.001$ & 0.759 & 0.008 & 0.001 \\
\hline I avoid excessive physical effort & 0.935 & 0.395 & 0.042 & 0.412 & 0.101 & 0.005 \\
\hline
\end{tabular}

value of $18-24.9 \mathrm{~kg} / \mathrm{m}^{2}$, is an important protective factor against CVDs.

Even $10 \%$ reduction of excess body weight causes a lot of positive changes in the cardiovascular system: it reduces left ventricular hypertrophy, the risk of coronary heart disease and sudden death, and lowers blood pressure, blood glucose, TC, LDL-C and TG [9].

Avoiding being overworked is another health behaviour with proven beneficial effects on the cardiovascular system. Among the studied women, significantly more of those with both CVDs and MS avoided being overworked than other groups of women.

The problems of too many working hours, too little sleep and no days off are quite common nowadays. Interestingly, Japan, Korea and Taiwan are the three countries in the world which created a new disease entity - 'cerebrovascular or heart disease associated with overworking', for which an employee receives compensation or a wage supplement [10]. Michishita et al. claim that too many working hours, too little sleep and too few days off lead to an excessive systolic blood pressure response to exercise. It is currently believed that such an increase in systolic blood pressure response to exercise results in an increased risk of hypertension and other CVDs [11].

Another health practice performed quite often by women suffering from both CVDs and MS was avoiding excessive physical effort, whereas healthy women were the least likely to avoid it. Increased physical activity is a beneficial lifestyle change for the cardiovascular system. Campbell et al. note that people with a history of myocardial infarction more frequently take up physical activity after than before the vessel incident and do it more often than people without CVDs [12]. According to the authors, the best form of physical activity in people with CVDs is walking, and 
a tool promoting the activity is a pedometer. Also, the distance to the nearest sports club or health centre plays a role. The farther the distance, the lower the probability of undertaking any physical activity $[13,14]$.

An underestimated preventive measure against developing CVDs and MS is a positive mental attitude as well as the so-called 'psychosocial risk factors' including depression, chronic psychosocial stress, socio-economic status, and education. The studied postmenopausal women most often had friends, a settled family life and a positive attitude.

According to Janion, among a majority of people with CVDs or MS there is no inner conviction and faith as to their effectiveness in improving bad habits, having a positive attitude and lifestyle change [15]. Ijzelenberg et al. also note that for people with CVDs and depression or low self-esteem the chance of lifestyle change is small [14]. Thorup et al. believe that physical activity, which leads to increased efficiency of the body, results in improved well-being, increased self-esteem and self-confidence. The author believes that a change in mental attitude results from improvement in the general state of health, and it is not a change in itself, or an effect of a desire to change one's life [13]. Vizza et al. draw attention to the impact of psychosocial factors on the further course of CVDs. Lifestyle change causes a reduction of depressive disorders by $90 \%$ and of stress by $85 \%$, and it improves the well-being by $87 \%$, with a consequent positive effect on the cardiovascular system [16].

Chida and Steptoe, based on a meta-analysis of 35 studies, reported that a positive mental attitude reduces mortality in a population of healthy individuals and patients with CVDs [17]. Sin also believes that a positive mental attitude, understood as optimism and life satisfaction, has a protective effect with respect to CVDs.

The author believes that a positive attitude lowers the risk of CVDs and sudden cardiovascular incidents in healthy individuals and also the risk of complications in people already suffering from CVDs [18]. On the other hand, Anthony et al. see a link between the optimistic approach to life and a reduction in mortality from coronary heart disease, but not from other CVDs or cancer [19].

Another group of health behaviours in the studied postmenopausal women was called 'preventive' and involved e.g.: adherence to medical recommendations, coming for the recommended visits, interest in how others avoid diseases, etc. Regular reporting for health checkups was undertaken most commonly by the women suffering from CVDs and MS. However, it is interesting that the women without these diseases tended to apply prophylaxis as well.
Diehl et al. point out the important role of GPS in preventing the development of CVDs and MS. [20], whereas Booner et al. point out the interesting fact that the technique of preventive measures against CVDs undertaken by GPs should depend on the actual cardiovascular risk in patients. Three strategies can be considered here. The 'positive' strategy, i.e. motivating patients to change their lifestyle, should be reserved for people with low cardiovascular risk wanting some change in life. The 'scaring' strategy should be addressed to people with a high risk of CVDs, a negative attitude and lacking motivation. The 'indirect' strategy is adequate for people who are healthy, but with some CVD risk factors [21].

Janion recognizes change in lifestyle as the primary method of prevention of cardiovascular diseases and an equivalent treatment method alongside drug administration. People with risk factors, with CVDs or MS show 'unrealistic optimism' - they are not aware of the real risk. Over $70 \%$ of them believe that their risk of heart attack is below average and they do not have to worry about prophylaxis or lifestyle change. This ignorance and acquired habits seem to be an obstacle to lifestyle change [15].

In conclusion, postmenopausal women working in agriculture more often perform some health behaviours if they have CVDs and MS diagnosed. These health behaviours are as follows: a) limited consumption of animal fat and sugar, b) regular reporting for health checkups, c) taking seriously recommendations from those who express concern about their health, d) some health practices: taking sufficient rest, avoiding being overworked and excessive physical effort. The frequency of health behaviours among postmenopausal women both healthy and with metabolic disorders and cardiovascular diseases is not sufficient and should be improved. Programmes to prevent diseases and promote health should be implemented to reduce the risk among healthy women as well as to relieve the symptoms among women diagnosed with CVDs and MS in order to maintain their physical and mental functions as long as possible.

\section{Acknowledgments}

This study was conducted at the Institute of Rural Health, Lublin, Poland, as part of the "Programme of Nationwide Health Screening for Residents of Rural Areas 2015-2016", supported by the Contribution Fund of Farmers' Social Insurance co-organized by the Agricultural Social Insurance Fund (KRUS).

\section{Conflict of interest}

The authors declare no conflict of interest. 


\section{References}

1. Sadłocha M, Skrzypules-Plinta V. Menopauza jako zdrowotne i psychologiczne doświadczenie w życiu kobiety. In: Raport Polki 50 plus. Zdrowie i jego zagrożenia. Fundacja MSD dla zdrowia kobiet, Warsaw 2016.

2. Gholi Z, Heidari-Beni M, Feizi A, Iraj B, Ascari G. The characteristics of pre-diabetic patients associated with body composition and cardiovascular disease risk factors in the Iranian population. J Res Med Sci 2016; 21: 20.

3. Mamcarz A, Podolec P, Kopeć G, et al. Wytyczne Grupy Roboczej PFP dotyczące zespołu metabolicznego 2009. Forum Profilaktyki 2009; 2 (14). Available at: www.pfp. edu.pl

4. Seneff S, Wainwright G, Mascitelli L. Is the metabolic syndrome caused by a high fructose, and relatively low fat, low cholesterol diet? Arch Med Sci 2011; 7: 8-20.

5. Olszanecka-Glinianowicz M, Kocełak P, Nylec M, Chudek J, Zahorska-Markiewicz B. Circulating visfatin level and visfatin/insulin ratio in obese women with metabolic syndrome. Arch Med Sci 2012; 8: 214-8.

6. Stońska Z. Proces starzenia się a promocja zdrowia i opieka zdrowotna dla kobiet w wieku 50+. In: Raport Polki 50 plus. Zdrowie i jego zagrożenia. Fundacja MSD dla zdrowia kobiet, Warsaw 2016.

7. Juczyński Z. Narzędzia pomiaru w promocji i psychologii zdrowia. Pracowania testów psychologicznych, Warsaw 2001; 110-6.

8. EUROASPIRE I and II Group; European Action on Secondary Prevention by Intervention to Reduce Events. Clinical reality of coronary prevention guidelines: a comparison of EUROASPIRE I and II in nine countries. EUROASPIRE I and II Group. European Action on Secondary Prevention by Intervention to Reduce Events. Lancet 2001; 357: 995-1001.

9. Zahorska-Markiewicz B, Podolec P, Kopeć G, et al. Polish Forum for Prevention Guidelines on overweight and obesity. Kardiol Pol 2008; 66: 594-6.

10. Park J, Kim Y, Cheng Y, Horie S. A comparison of the recognition of overwork-related cardiovascular disease in Japan, Korea, and Taiwan. Ind Health 2012; 50: 17-23.

11. Michishita R, Ohta M, Ikeda M, Jiang Y, Yamato H. Associations of the work duration, sleep duration and number of holidays with an exaggerated blood pressure response during an exercise stress test among Wolkers. Sangyo Eiseigaku Zasshi 2016; 58: 11-20.

12. Campbell NC, Ritchie LD, Thain J, Deans HG, Rawles JM, Squair JL. Secondary prevention in coronary heart disease: a randomised trial of nurse led clinics in primary care. Heart 1998; 80: 447-52.

13. Thorup CG, Grønkjær M, Spindler H, et al. Pedometer use and self-determined motivation for walking in a cardiac telerehabilitation program: a qualitative study. BMC Sports Sci Med Rehabil 2016; 8: 24.

14. IJzelenberg W, Maurits IM, van Tulder W, et al. The effect of a comprehensive lifestyle intervention on cardiovascular risk factors in pharmacologically treated patients with stable cardiovascular disease compared to usual care: a randomised controlled trial. BMC Cardiovasc Disord 2012; 12: 71.

15. Janion M. Profilaktyka pierwotna chorób układu krążenia. Studia Medyczne 2006; 3: 107-20.

16. Vizza J, Neatrour DM, Felton PM, Ellsworth DL. Improvement in psychosocial functioning during an intensive cardiovascular lifestyle modification program. J Cardiopulm Rehabil Prev 2007; 27: 376-83.

17. Chida Y, Steptoe A. Positive psychological well-being and mortality: a quantitative review of prospective observational studies. Psychosom Med 2008; 70: 741-56.
18. Sin NL. The protective role of positive well-being in cardiovascular disease: review of current evidence, mechanisms, and clinical implications. Curr Cardiol Rep 2016; 18: 106.

19. Anthony EG, Kritz-Silverstein D, Barrett-Connor E. Optimism and mortality in older men and women: the Rancho Bernardo Study. J Aging Res 2016; 2016: 5185104.

20. Diehl K, Gansefort D, Herr RM, et al. Physician gender and lifestyle counselling to prevent cardiovascular disease: a nationwide representative study. J Public Health Res 2015; 4: 534.

21. Bonner C, Jansen J, McKinn S, et al. Communicating cardiovascular disease risk: an interview study of General Practitioners' use of absolute risk within tailored communication strategies. BMC Fam Pract 2014; 15: 106. 